\title{
Effect of different level of drip irrigation on growth, yield and water use efficiency of okra (Abelmoschus esculentus L.)
}

\section{Daleshwar Rajak and Pravin Dahiphale}

See end of the Paper for authors' affiliation

Correspondence to : Daleshwar Rajak Zonal Research Station (BAU), Darisai East Singhbhum (Jharkhand) India Email : drajak76@rediffmail. com
- ABSTRACT : A field experiment was conducted at Zonal Research Station, Darisai, East Singhbhum, Jharkhand during 2016-2017 to estimate the water requirement for increasing the productivity of okra. The experiments were laid out in Randomized Block Design with five treatments which included four level of drip irrigation viz., 100, 80, 60 and 40 per cent evapotranspiration (ET) and surface irrigation at 1.0 IW/CPE and were replicated thrice. The results revealed that higher yields ( $\left.160.52 \mathrm{q} \mathrm{ha}^{-1}\right)$ was recorded in treatment $\mathrm{T}_{1}$ - Drip irrigation at 100 per cent ET with maximum plant height $(102.6 \mathrm{~cm})$ and number of branches plant ${ }^{-1}(2.08)$ and was significantly superior over rest treatment. The water use efficiency of $58.34 \mathrm{~kg} / \mathrm{ha} / \mathrm{mm}$ was recorded in drip irrigation at 40 per cent ET. The maximum benefit-cost ratio (1.40) was noted in $\mathrm{T}_{1}$ - Drip irrigation at 100 per cent ET and minimum (0.61) in $\mathrm{T}_{4}$ - Drip irrigation at 40 per cent ET.

- KEY WORDS : Okra, Drip irrigation, Surface irrigation, Water requirement, Water use efficiency, Economics

- HOW TO CITE THIS PAPER : Rajak, Daleshwar and Dahiphale, Pravin (2019). Effect of different level of drip irrigation on growth, yield and water use efficiency of okra (Abelmoschus esculentus L.). Internat. J. Agric. Engg., 12(1) : 124-128, DOI: 10.15740/HAS/IJAE/12.1/124-128. Copyright@2019: Hind Agri-Horticultural Society. 